\title{
Persepsi Pelanggan terhadap Penerapan Protokol Kesehatan dalam Upaya Meningkatkan Kualitas Pelayanan Selama Era New Normal pada Restoran di Kota Denpasar-Bali
}

\author{
Ni Putu Ariesta Budiani
}

Manajemen Tata Hidangan, Jurusan Hospitaliti, Politeknik Pariwisata Bali

Jl. Dharmawangsa, Kampial - Badung, Indonesia

ariestabudiani@gmail.com

\begin{tabular}{l|l|l} 
Received: Mei, 2021 & Accepted: Mei, 2021 & Published: June, 2021
\end{tabular}

\begin{abstract}
In implementing business ethics in the New Normal Era for restaurants, it must follow established health procedures to convince customers that the business sector is in accordance with standards (safety. Therefore, it is necessary to conduct research to determine the extent to which tourism business actors, in this case the food / restaurant service business, have implemented the health protocol. Based on the Guidelines for the Implementation of Cleanliness, Health, Safety and Environmental Sustainability (CHSE) in Restaurants / Restaurants, there are 3 dimensions in implementing health protocols with 33 existing attributes related to service quality to be analyzed. Based on the assessment of 165 respondents spread across 15 restaurants (rated 4-5 star according to TrpAdvisor) in Denpasar, it is concluded that the overall customer perception of the application of health protocols in an effort to improve service quality during the New Normal era, received the average value of 3.34 which in this case is included in the quite good category. This shows that the 15 restaurants representing well-known restaurants in Denpasar have not implemented health protocols optimally. Thus it is suggested that the government immediately hold a consistent and serious socialization and counseling to restaurants.
\end{abstract}

Keywords: perception, restaurant, CHSE, covid-19

\begin{abstract}
Abstrak
Dalam menerapkan etika bisnis di Era New Normal bagi sektor bisnis restoran, harus mengikuti prosedur kesehatan yang telah ditetapkan untuk menyakinkan kepada pelanggan bahwa sektor bisnis tersebut sudah sesuai standar (safety). Untuk itu perlu diadakan penelitian guna mengetahui sejauh mana pelaku bisnis pariwisata dalam hal ini usaha jasa pangan/ restoran sudah menerapkan protokol kesehatan tersebut. Berdasarkan buku Panduan Pelaksanaan Cleanliness, Health, Safety and Environmental Sustainability (CHSE) atau yang
\end{abstract}


selanjutnya disebut Panduan Pelaksanaan Kebersihan, Kesehatan, Keselamatan, dan Kelestarian Lingkungan di Restoran/Rumah Makan terdapat 3 dimensi dalam penerapan protokol kesehatan dengan 33 atribut yang ada terkait kualitas pelayanan yang akan dianalisis. Berdasarkan penilaian 165 responden yang tersebar di 15 restoran (peringkat 4-5 star menurut TrpAdvisor) di Denpasar diperoleh kesimpulan bahwa persepsi pelanggan secara keseluruhan terhadap penerapan protokol kesehatan dalam upaya meningkatkan kualitas pelayanan selama era New Normal pada 15 restoran di Kota Denpasar, Bali, mendapat nilai rata-rata 3.34 yang dalam hal ini termasuk dalam katagori cukup baik. Ini menunjukkan bahwa ke-15 restoran yang mewakili restoran ternama di Denpasar belum menerapkan protokol kesehatan dengan optimal. Dengan demikian disarankan kepada pemerintah agar segera mengadakan sosialisasi dan penyuluhan yang konsisten dan serius ke restoran-restoran.

Kata Kunci: persepsi, restoran, CHSE, covid-19

\section{PENDAHULUAN}

Sejak pertama kali dinyatakan terdapat kasus warga Indonesia yang terjangkit virus corona sekitar bulan Maret 2020, kondisi keamanan warga Indonesia sangat mencekam dari ancaman virus tersebut. Ancaman virus corona yang disebut dengan Covid-19 mempengaruhi hampir seluruh lini kehidupan termasuk kondisi pariwisata yang sangat jelas terpuruk. Apalagi virus ini pertama kali disebarkan oleh warga Negara China dan kita tahu bahwa China merupakan wisatawan nomor dua tertinggi setelah Australia berdasarkan informasi dari Badan Statistik Provinsi Bali. Sehingga dampaknya sangat dirasakan oleh seluruh warga masyarakat termasuk masyarakat Bali yang sebagian besar mengandalkan sektor pariwisata sebagai sumber pendapatan. Sementara, menurut Perhimpunan Hotel dan Restoran Indonesia (PHRI), penurunan tingkat okupansi di sekitar 6.000 hotel di seluruh Indonesia mencapai hingga 50 persen sejak awal tahun hingga saat ini. Tingkat hunian hotel di Bali rata-rata turun hingga 70 persen sejak merebaknya wabah Covid-19. Hal ini juga tentunya berdampak bagi usaha jasa pangan dan usaha ritel.

Startup penyedia layanan kasir digital untuk lebih dari 30 ribu merchant di Indonesia, Moka menyatakan industri makanan dan minuman (food and beverage/F\&B) menjadi Industri yang paling terdampak virus corona (Covid-19). Kemudian disusul industri jasa dan ritel. Dan berdasarkan observasi yang dilakukan di 17 kota, sebanyak 13 kota mengalami penurunan pendapatan harian yang signifikan akibat Covid-19. Begitu juga dengan Bali dan Surabaya masing-masing mengalami penurunan sebesar 18 persen untuk Bali dan 26 persen untuk Surabaya.

Selain berdampak terhadap perekonomian, pandemi Covid-19 merubah tatanan masyarakat dunia. Guna mencegah penularan wabah virus corona yang meluas, masyarakat diimbau bahkan dipaksa untuk tinggal di rumah. Sekolah, bekerja bahkan beribadah pun dianjurkan untuk dilakukan di rumah saja. Hampir semua negara mengimbau warganya untuk tidak beraktivitas di luar rumah jika tidak ada kepentingan yang mendesak. Dengan adanya anjuran seperti ini menyebabkan banyak orang enggan untuk bepergian keluar rumah termasuk membeli makanan ke tempat-tempat umum seperti rumah makan dan restoran. Pengunjung lama-lama semakin berkurang sehingga pendapatan jadi menurun dan perekonomian jadi terhambat karena banyak rumah makan dan restoran tutup. Di lain sisi perkembangan terjangkitnya wabah pandemi covid-19 ini tidak menunjukkan penurunan, melainkan malah menunjukkan peningkatan. Melihat kondisi seperti ini akhirnya pemerintah mengumumkan kepada masyarakat untuk mulai 
menerapkan aktivitas normal baru atau istilah lainnya adalah new normal pada aktivitas keseharian nantinya (Era new normal).

Ketua Tim Pakar Gugus Tugas Percepatan Penanganan Covid-19 Wiku Adisasmita kepada Kompas.com. mengatakan, new normal adalah perubahan perilaku untuk tetap menjalankan aktivitas normal namun dengan ditambah menerapkan protokol kesehatan guna mencegah terjadinya penularan Covid-19. Hal ini juga ditegaskan oleh Bapak Presiden bahwa masyarakat harus bisa berkompromi, hidup berdampingan, dan berdamai dengan Covid-19 agar tetap produktif. Disebutkan juga bahwa New Normal merupakan kebijakan membuka kembali aktifitas ekonomi, sosial dan kegiatan publik secara terbatas. Dengan menggunakan standar atau protokol kesehatan yang ditetapkan oleh Pemerintah. Selanjutnya, pada tanggal 20 Mei 2020, Pemerintah pusat melalui Kemenkes mengeluarkan; Kepmenkes No. HK.01.07/Menkes/328/2020 tentang Panduan Pencegahan Dan Covid-19 Di Tempat Kerja Perkantoran Dan Industri Dalam Mendukung Keberlangsungan Usaha Pada Situasi Pandemi.

Peningkatan kesadaran masyarakat Indonesia dan dunia terhadap kebersihan, kesehatan, keselamatan, dan kelestarian lingkungan, sangat besar disebabkan karena adanya pandemi Covid-19. Sehingga pola permintaan dan perilaku wisatawan ke depan akan sangat dipengaruhi kesadaran terhadap kebersihan, kesehatan, keselamatan, dan kelestarian lingkungan yang tinggi. Maka dunia pariwisata harus bersiap diri untuk dapat memberikan jaminan kebersihan, kesehatan, keselamatan, dan kelestarian lingkungan yang tinggi akan produk dan pelayanan yang diberikan kepada wisatawan. Melihat tantangan tersebut pemerintah khususnya Kemenparekraf perlu membuat panduan praktis bagi industri pariwisata dalam menyiapkan produk dan pelayanan yang bersih, sehat, aman, dan ramah lingkungan khususnya restoran/ rumah Makan. Panduan ini yang nantinya dijadikan standar protokol kesehatan di dunia pariwisata. Akhirnya di bulan Juli 2020 akhirnya Kemenparekraf mengeluarkan Buku Panduan Pelaksanaan Kebersihan, Kesehatan, Keselamatan, dan Kelestarian Lingkungan di Restoran/ Rumah Makan.rDalam rangka melaksanakan protokol kesehatan bagi masyarakat produktif untuk pencegahan dan pengendalian Corona Virus Disease 2019 (Covid-19).

Dalam menerapkan etika bisnis di Era New Normal bagi sektor bisnis pariwisata seperti restoran, harus mengikuti prosedur kesehatan yang telah ditetapkan untuk menyakinkan kepada pelanggan bahwa sektor bisnis tersebut sudah sesuai standar (safety). Penerapan standar kesehatan tersebut tidak hanya diperuntukkan bagi kesehatan pelanggan tetapi juga kesehatan karyawan. Pelanggan akan semakin yakin bahwa bisnis tersebut aman dikunjungi jika tempat tersebut menerapkan standar kesehatan ke semua lini. Demi memperoleh kepercayaan konsumen itu Perusahaan tentunya akan mengeluarkan sejumlah biaya yang tidak sedikit untuk menerapkan Etika dalam Berbisnis di Era New Normal ini, seperti disenfektan, hand sanitizer, thermometer suhu, dan lain sebagainya yang harus dilakukan setiap hari untuk keamanan dan kesehatan pelanggan dan karyawan.

Begitu juga dengan usaha jasa pangan di Bali yang kini sudah mulai berangsurangsur beroperasi. Menurut data yang diperoleh di TripAdvisor berdasarkan penilaian pelanggan terdapat 15 Restoran di Denpasar yang mendapat banyak ulasan dan peringkat/ peringkat $4-5$ star. Adapun datanya dituangkan dalam tabel berikut.

Tabel 1: Rekapitulasi Restoran di Kota Denpasar - Bali, Tahun 2020

[Sumber: TripAdvisor, 2020]

\begin{tabular}{ccccc}
\hline No & Nama Restoran & \multicolumn{1}{c}{ Lokasi } & Rengking & Kecamatan \\
\hline 1 & Goemerot Restaurant & $\begin{array}{l}\text { Jl. Gatot Subroto Barat, } \\
\text { no. 99W, Ubung, }\end{array}$ & 4,4 & Denpasar \\
& & & Utara
\end{tabular}




\begin{tabular}{|c|c|c|c|c|}
\hline \multirow{3}{*}{2} & \multirow{3}{*}{$\begin{array}{l}\text { Massimo, Italian } \\
\text { Restoran }\end{array}$} & \multicolumn{3}{|l|}{ Denpasar } \\
\hline & & Jl. Danau Tamblingan & 4,6 & Denpasar \\
\hline & & \multicolumn{2}{|l|}{ 228, Sanur } & Selatan \\
\hline \multirow[t]{2}{*}{3} & \multirow{2}{*}{$\begin{array}{l}\text { Ayam Bakar Taliwang } \\
\text { Baru }\end{array}$} & Jl. Teuku Umar 10, & 4,3 & Denpasar \\
\hline & & \multicolumn{2}{|l|}{ Denpasar } & Barat \\
\hline \multirow[t]{2}{*}{4} & \multirow[t]{2}{*}{ Babi Guling Chandra } & Jl. Teuku Umar no. 232, & 4,3 & Denpasar \\
\hline & & \multicolumn{2}{|l|}{ Denpasar } & Barat \\
\hline \multirow[t]{2}{*}{5} & \multirow[t]{2}{*}{ Warung Be Sanur } & Jl. Tantular I no. 99, & 4,4 & Denpasar \\
\hline & & & Timur \\
\hline \multirow[t]{2}{*}{6} & \multirow{2}{*}{$\begin{array}{l}\text { Gosha Kitchen \& } \\
\text { Patisserie }\end{array}$} & Jl. Tukad Gangga no 28, & 4,4 & Denpasar \\
\hline & & Denpasar & & Timur \\
\hline \multirow[t]{2}{*}{7} & \multirow[t]{2}{*}{ Warung Subak } & \multirow{2}{*}{$\begin{array}{l}\text { Jl. Astasura no.5, } \\
\text { Denpasar }\end{array}$} & 4,4 & Denpasar \\
\hline & & & & Utara \\
\hline \multirow{2}{*}{8} & \multirow{2}{*}{ Depot Gimbo } & \multirow{2}{*}{$\begin{array}{l}\text { Jl. Imam Bonjol 350, } \\
\text { Denpasar }\end{array}$} & 4,5 & Denpasar \\
\hline & & & & Barat \\
\hline \multirow[t]{2}{*}{9} & \multirow[t]{2}{*}{ Warung Mak Beng } & \multirow{2}{*}{$\begin{array}{l}\text { Jl. Hang Tuah no. } 45 \text {, } \\
\text { Sanur - Denpasar }\end{array}$} & 4,5 & Denpasar \\
\hline & & & & Selatan \\
\hline \multirow[t]{2}{*}{10} & \multirow[t]{2}{*}{ Warung Bendega } & \multirow{2}{*}{$\begin{array}{l}\text { Jl. Cok Agung Tresna no. } \\
\text { 37A, Denpasar }\end{array}$} & 4,4 & Denpasar \\
\hline & & & & Timur \\
\hline \multirow[t]{2}{*}{11} & \multirow{2}{*}{ Nelayan Bay Restaurant } & \multirow{2}{*}{$\begin{array}{l}\text { Jl. Setapak, Sanur, } \\
\text { Denpasar }\end{array}$} & 4,3 & Denpasar \\
\hline & & & & Selatan \\
\hline \multirow[t]{3}{*}{12} & \multirow[t]{3}{*}{ Roti Canai dan Teh Tarik } & Jl. By Pass Ngurah Rai, & 4,4 & Denpasar \\
\hline & & No. $108 / 415$, Sanur, & & Selatan \\
\hline & & Denpasar & & \\
\hline 13 & Soul on the Beach & Jl.Pantai Sindhu, Sanur, & 4,6 & Denpasar \\
\hline & & Denpasar & & Selatan \\
\hline 14 & Lilla Warung & Jl. Bumi Ayu no. 6, Sanur, & 4,5 & Denpasar \\
\hline & & Denpasar & & Selatan \\
\hline 15 & Apa Kabar Restaurant & Jl. Danau Tamblingan & 4,4 & Denpasar \\
\hline & & 195, Sanur, Denpasar. & & Selatan \\
\hline
\end{tabular}

Berdasarkan uraian pada latar belakang masalah di atas, maka penelitian ini bertujuan untuk mengetahui persepsi pelanggan terhadap penerapan protokol kesehatan dalam upaya meningkatkan kualitas pelayanan selama Era New Normal pada restoran di Kota Denpasar, Bali.

Wall \& Berry (2007) meneliti tentang pengalaman makan pada restoran formal setidaknya melibatkan 3 faktor penting. Walaupun kualitas makanan sangat mendasar, suasana dan kinerja layanan sangat berpengaruh pada penilaian pelanggan bagi sebuah restoran. Terdapat beberapa faktor kunci dalam penilaian pengalaman makan pada sebuah restoran yaitu : faktor fungsi (elemen suasana, desain dan teknikal ) dan faktor manusia (elemen kinerja, prilaku, penampilan karyawan).

Erfiana, et.al. (2014) meneliti tentang tingkat pengaruh dimensi kualitas pelayanan meliputi tangibles, reliability, responsiveness, assurance dan emphaty terhadap kepuasan konsumen Restoran Jepang Saboten Shokudo. Hasil penelitian menujukkan bahwa kualitas pelayanan yang terdiri dari lima variabel berpengaruh signifikan terhadap kepuasan konsumen. Urutan variabel yang paling berpengaruh adalah variabel tangibles (bukti fisik), responsiveness (ketanggapan), emphaty (perhatian), assurance (jaminan), dan realibility (kehandalan).

Tusukan, et.al. (2016), meneliti tentang pentingnya lingkungan fisik restoran bagi pelanggan dari Turki. Penelitian ini secara empiris menganalisis tingkat kepentingan elemen lingkungan fisik sebuah restoran untuk pelanggan di Turki dan meneliti hubungan antara restoran dengan unsur-unsur lingkungan fisik dan karakteristik pelanggan. 
Hendriyani (2018) menghasilkan penelitian yang menunjukkan bahwa peran lingkungan fisik dalam kepuasan pelanggan di restoran di Bali secara keseluruhan dalam kondisi baik. Faktor yang paling menentukan kepuasan pelanggan adalah faktor atmosfer yang diikuti oleh faktor estetika fasilitas. Variabel yang paling menentukan kepuasan pelanggan adalah suhu kamar yang nyaman diikuti oleh furnitur bersih

Hendriyani, et.al. (2019) meneliti tentang indikator atau variabel mana yang berperan dalam kualitas pelayanan dan indikator atau variabel mana yang memiliki peranan penting dalam kualitas pelayanan dan peranan lingkungan fisik pada 26 restoran di kota Denpasar. Ini menunjukkan bahwa ke-26 restoran yang juga menjadi rekomendasi dari Tripadvisor sudah menerapkan kualitas pelayanan dan yang baik serta menyediakan fasilitas yang nyaman guna memberikan kepuasan pelayanan bagi pelanggan.

Berdasarkan tinjauan keempat jurnal tersebut dapat disimpulkan bahwa kualitas pelayanan yang meliputi variable tangible (bukti fisik) seperti lingkungan fisik yang bersih dan nyaman serta terjamin (keamanan dan kesehatan), begitu juga dengan perhatian dan kehandalan karyawannya menjadi penentuan kepuasan pelangggan di restoran.

\section{METODE PENELITIAN}

Penelitian ini menggunakan analisis kuantitatif karena terdapat pengolahan data mengunakan angka-angka. Kemudian analisis berdasarkan perhitungan frekwensi yang dipergunakan dalam penelitian ini akan didukung dengan analisis deskriptif kualitatif atau interpretasi data hasil penelitian. Pendekatan ini diharapkan dapat membantu peneliti untuk meneliti variable-variabel dari fenomena yang diteliti, yaitu penerapan protokol kesehatan selama era new normal pada restoran di Kota Denpasar, Bali.

Dalam penelitian ini variable dan item dicari berdasarkan Panduan Pelaksanaan Cleanliness, Health, Safety and Environmental Sustainability (CHSE).

Penelitian ini dilakukan pada 15 restoran terbaik di Kota Denpasar, Bali berdasarkan dari data TripAdvisor. Lokasi restoran sebagai sample dalam penelitian ini tersebar pada 15 restoran di Kota Denpasar, Bali. Responden dalam penelitian ini adalah pelanggan restoran yang sedang atau pernah mengunjungi 15 restoran di Kota Denpasar, Bali. Teknik penentuan sampel yang digunakan dalam penelitian ini adalah non-probability sampling dengan metode accidental sampling. Kusmayadi dan Sugiarto (2000:140) menjelaskan penarikan contoh dengan menggunakan non probability sampling membuat peluang seseorang untuk menjadi responden tidak diketahui.

Sedangkan untuk analisis data menggunakan analisis faktor, Supranto (2004:314) menyarankan bahwa besarnya sampel (n) dalam analisis faktor paling sedikit empat atau lima kali banyaknya variabel. Atas pertimbangan waktu, biaya dan kebutuhan data yang sesuai dengan analisis faktor, maka jumlah sampel dalam penelitian ini ditetapkan 33 variabel dikalikan 5 yaitu 165 orang responden.

Dalam penelitian ini variabel atau indikator diukur secara ordinal dengan menggunakan skala Likert. Skala ini digunakan untuk mengukur sikap dari jenjang yang paling positif ke jenjang yang paling negatif (Kusmayadi dan Sugiarto,2000). Sebelum instrumen penelitian digunakan untuk mengumpulkan data, maka instrumen tersebut harus diuji dengan uji validitas dan reliabilitas. Tujuan uji validitas dan reliabilitas adalah untuk menguji apakah angket tersebut dapat mengukur apa yang seharusnya diukur dan memiliki konsistensi hasil bila digunakan oleh peneliti dan responden yang berbeda.

\section{HASIL DAN PEMBAHASAN}

\subsection{Hasil Uji Validitas dan Reliabilitas}

Pengujian validitas ini menggunakan 33 orang responden yang diteliti $(\mathrm{N}=33)$. 33 orang ini dianggap sudah berdistribusi secara normal. Hasil uji validitas pada penelitian 
ini menunjukkan interval 0,305 sampai dengan 0,996 yang artinya instrument penelitian telah memenuhi syarat validitas dengan nilai koefisien korelasi item-total masing-masing yang lebih besar dari $0,3\left(R_{i}>0,3\right)$. Dengan demikian instrumen penelitian layak atau valid digunakan sebagai pengumpul data.

Selanjutnya dilakukan uji Reliabilitas adalah indeks yang menunjukkan sejauh mana suatu alat ukur dapat dipercaya atau dapat diandalkan untuk mengambil data. Uji reliabilitas dilakukan dengan uji varians alfa-Cronbanch. Apabila nilai alfa-Cronbach $\mathrm{r}_{\mathrm{i}}>$ 0,6; maka selanjutnya instrumen tersebut dinyatakan valid dan dapat dipergunakan dalam penelitian. Hasil uji reliabilitas instrumen dalam penelitian ini, koefisien alphanya 0,835. Dengan nilai alfa-cronbach 0,835 > 0,6 sehingga instrumen penelitian ini dapat dipercaya, andal dan akurat sebagai pengumpul data.

\subsection{Karakteristik Responden}

Penelitian ini menggunakan pendapat dari responden yang merupakan pelanggan, baik berkebangsaan Indonesia maupun asing. Dalam hal ini pelanggan yang dimaksud adalah pelanggan yang sedang dan pernah berkunjung ke restoran yang menjadi objek penelitian selama periode penelitian. Uraian tentang karakteristik responden dalam hal ini adalah: jenis kelamin, umur, jabatan /posisi pekerjaan, sumber informasi tentang restoran, dan frekwensi kunjungan ke restoran. Dari 165 responden yang teridentifikasi sebagai berikut :

1) Menurut kelompok jenis kelamin untuk laki-laki yaitu sebanyak 94 orang atau 57\% sedangkan sisanya 71 orang atau $43 \%$ adalah perempuan.

2) Berdasarkan kelompok umur responden 101 orang atau sekitar $61 \%$ berada pada rentang umur antara 17 - 25 tahun, 41 orang atau sekitar $22 \%$ berada pada rentang umur 26 - 36 tahun, dan 23 orang atau sekitar $17 \%$ berada pada rentang umur antara 37 - 50 tahun. Ini menunjukkan bahwa masyarakat dari kalangan remaja hingga dewasa banyak mengunjungi restoran di sekitar wilayah Denpasar untuk ngobrol dan berkumpul bersama teman, sahabat, hingga sanak saudara dan keluarga. Sehingga tradisi makan bersama di luar rumah sudah menjangkit di kota Denpasar walau dimasa pandemi seperti ini hanya saja mungkin tidak seramai sebelum pandemi.

3) Terpilih berdasarkan posisi jabatan atau pekerjaan yang dilakukan menunjukkan bahwa responden terbanyak menempati posisi mahasiswa atau murid sebanyak 111 orang atau $67 \%$, diikuti karyawan/ staf sebanyak 46 orang atau $28 \%$, dan 5 orang atau $3 \%$ memiliki usaha sendiri (wiraswasta), dan 3 orang atau $2 \%$ sebagai PNS.

4) Sumber informasi tentang restoran berdasarkan tabulasi data responden mengetahui restoran sebagian besar dari teman dan web atau media sosia.

5) Berdasarkan frekwensi kunjungan ke restoran menunjukkan bahwa rata-rata tamu berkunjung 1 -2 kali selama masa penelitian.

\subsection{Deskripsi Data}

Dalam deskripsi terhadap kuesioner penelitian akan diuraikan persepsi responden terhadap penerapan protokoler kesehatan dilihat dari 3 dimensi yaitu dimensi penerimaan terdiri dari 8 variabel, kemudian dimensi pelayanan makanan dan minuman terdiri dari 15 variabel, dan dimensi pembayaran dan pintu keluar terdiri dari 10 variabel. Dimana penilaian secara kuantitatif menggunakan skala interval dengan mengintegrasikan rata-rata skor menurut kategori penilaiannya. Rumus interval kelas :

Nilai tertinggi $=5$

Nilai rendah $=1$

Rentang 5-1 = 4 


$$
\begin{aligned}
\text { C(Interval Kelas) } & =\frac{\mathrm{R} \text { (Range) }}{\mathrm{K}(\text { Jumlah Klasifikasi) }} \\
\mathrm{C} & =\frac{4}{5} \\
& =0,80
\end{aligned}
$$

Dari nilai interval kelas maka diperoleh batas-batas klasifikasi (kriteria) dengan kategori penilaian seperti pada Tabel 2 .

\begin{tabular}{ccc}
\multicolumn{3}{c}{ Tabel 2: Kelas interval dan kategori } \\
\hline No & $\begin{array}{c}\text { Kelas } \\
\text { Interval }\end{array}$ & Kategori \\
\hline 1 & $1,00-1,79$ & Sangat Tidak Baik \\
2 & $1,80-2,59$ & Tidak Baik \\
3 & $2,60-3,39$ & Cukup Baik \\
4 & $3,40-4,19$ & Baik \\
5 & $4,20-5,00$ & Sangat Baik \\
\hline
\end{tabular}

\subsection{Rekapitulasi Distribusi Frekuensi Jawaban Responden}

Persepsi pelanggan (responden) terhadap penerapan protokol kesehatan pada 15 restoran yang mendapat peringkat 4-5 star (versi TripAdvisor) dan juga terdaftar di Dinas Pariwisata di Kota Denpasar yang berjumlah 165, dapat dilihat dari masing-masing dimensi pada tabel berikut.

\begin{tabular}{|c|c|c|c|c|c|c|c|c|c|}
\hline \multirow[b]{2}{*}{ Dimensi } & \multirow[b]{2}{*}{ Variabel } & \multicolumn{5}{|c|}{ Nilai Jawaban } & \multirow{2}{*}{$\begin{array}{l}\text { Total } \\
\text { Nilai }\end{array}$} & \multirow{2}{*}{$\begin{array}{c}\text { Rata } \\
- \\
\text { Rata }\end{array}$} & \multirow{2}{*}{ Keterangan } \\
\hline & & $\begin{array}{l}\text { STB } \\
(1)\end{array}$ & $\begin{array}{l}\text { TB } \\
(2)\end{array}$ & $\begin{array}{l}\text { CB } \\
\text { (3) }\end{array}$ & $\begin{array}{c}\text { B } \\
(4)\end{array}$ & $\begin{array}{l}\text { SB } \\
\text { (5) }\end{array}$ & & & \\
\hline & $\mathrm{X} 1$ & 1 & 72 & 144 & 208 & 140 & 565 & 3.42 & Baik \\
\hline & $\mathrm{X} 2$ & 6 & 58 & 141 & 204 & 160 & 569 & 3.45 & Baik \\
\hline Penerimaan & $\mathrm{X} 3$ & 11 & 72 & 96 & 164 & 225 & 568 & 3.44 & Baik \\
\hline (Area Pintu & $\mathrm{X} 4$ & 13 & 76 & 96 & 192 & 170 & 547 & 3.32 & Cukup Baik \\
\hline \multirow[t]{4}{*}{ Masuk) } & $\mathrm{X} 5$ & 9 & 100 & 171 & 140 & 70 & 490 & 2.97 & Cukup Baik \\
\hline & $\mathrm{X} 6$ & 10 & 62 & 195 & 164 & 90 & 521 & 3.16 & Cukup Baik \\
\hline & $\mathrm{X} 7$ & 10 & 130 & 156 & 132 & 25 & 453 & 2.75 & Cukup Baik \\
\hline & $\mathrm{X} 8$ & 17 & 132 & 135 & 124 & 30 & 438 & 2.65 & Cukup Baik \\
\hline Total & & & & & & & & 25.20 & \\
\hline Rata-Rata & & & & & & & & 3.14 & Cukup Baik \\
\hline
\end{tabular}

Tabel 3: Distribusi Frekuensi Nilai Jawaban Responden dari Dimensi Penerimaan (N=165) [Sumber : data olahan]

Berdasarkan Tabel 3 ditemukan bahwa persepsi pelanggan terhadap penerapan protokol kesehatan dalam upaya meningkatkan kualitas pelayanan selama era New Normal pada 15 Restoran di Kota Denpasar, dilihat dari dimensi penerimaan atau yang bisa disebut dengan area pintu masuk mendapat nilai rata-rata 3.14 yang berarti cukup baik. Hal ini berdasarkan pada penilaian pelanggan yang menyatakan bahwa sebagian besar variabel daripada dimensi penerimaan adalah rata-rata cukup baik, namun ada yang menyatakan baik yaitu dari variable (1) Tersedia aturan pengelolaan arus lalu lintas dan kerumunan di area parkir, (2)Tersedia area khusus/ ruang tunggu bagi pengemudi 
dilengkapi fasilitas cuci tangan/hand sanitizer dan tisu, dengan memperhatikan jarak aman minimal 1 (satu) meter, (3)Tersedia area dan peralatan pemeriksaan suhu tubuh dan kondisi kesehatan tamu dan karyawan. Hal ini juga didukung dengan adanya observasi langsung yang menunjukkan bahwa memang sebagian besar restoran yang menjadi objek penelitian tersebut menyediakan area dan fasilitas tersebut (seperti pada foto dokumentasi terlampir). Sedangkan variable lainnya belum diterapkan secara optimal seperti area untuk membersihkan peralatan tamu tidak tersedia khusus, begitu juga dengan peralatan seperti sprey disinfektan/cairan pembersih peralatannya tidak disediakan hanya ada hand satitizer. Selain itu jarang restoran-restoran memasang penanda titik kumpul, yang ada hanya jalur evakuasi dan membatasi jumlah kursi dalam satu meja.

Tabel 4: Distribusi Frekuensi Nilai Jawaban Responden dari Dimensi Pelayanan Makanan dan Minuman $(\mathrm{N}=165)$

\begin{tabular}{|c|c|c|c|c|c|c|c|c|c|}
\hline \multirow[b]{2}{*}{ Dimensi } & \multirow[b]{2}{*}{ Variabel } & \multicolumn{5}{|c|}{ Nilai Jawaban } & \multirow{2}{*}{$\begin{array}{l}\text { Total } \\
\text { Nilai }\end{array}$} & \multirow{2}{*}{$\begin{array}{c}\text { Rata } \\
- \\
\text { Rata }\end{array}$} & \multirow{2}{*}{ Keterangan } \\
\hline & & $\begin{array}{l}\text { STB } \\
\text { (1) }\end{array}$ & $\begin{array}{l}\text { TB } \\
\text { (2) }\end{array}$ & $\begin{array}{l}\text { CB } \\
\text { (3) }\end{array}$ & $\begin{array}{c}\text { B } \\
\text { (4) }\end{array}$ & $\begin{array}{l}\text { SB } \\
\text { (5) }\end{array}$ & & & \\
\hline & $\mathrm{X} 9$ & 5 & 66 & 156 & 220 & 100 & 547 & 3.32 & Cukup Baik \\
\hline & $\mathrm{X} 10$ & 9 & 86 & 111 & 200 & 130 & 536 & 3.25 & Cukup Baik \\
\hline & $\mathrm{X} 11$ & 0 & 18 & 99 & 204 & 360 & 681 & 4.13 & Baik \\
\hline & $\mathrm{X} 12$ & 0 & 24 & 90 & 268 & 280 & 662 & 4.01 & Baik \\
\hline & $\mathrm{X} 13$ & 2 & 40 & 198 & 232 & 95 & 567 & 3.44 & Baik \\
\hline Pelayanan & $\mathrm{X} 14$ & 2 & 22 & 90 & 276 & 265 & 655 & 3.97 & Baik \\
\hline Makanan & X15 & 0 & 38 & 108 & 264 & 220 & 630 & 3.82 & Baik \\
\hline \multirow[t]{8}{*}{ Dan Minuman } & $\mathrm{X} 16$ & 0 & 10 & 144 & 260 & 235 & 649 & 3.93 & Baik \\
\hline & $\mathrm{X} 17$ & 3 & 80 & 162 & 212 & 75 & 532 & 3.22 & Cukup Baik \\
\hline & $\mathrm{X} 18$ & 1 & 96 & 192 & 156 & 65 & 510 & 3.09 & Cukup Baik \\
\hline & $\mathrm{X} 19$ & 1 & 52 & 180 & 220 & 120 & 573 & 3.47 & Baik \\
\hline & $\mathrm{X} 20$ & 1 & 40 & 207 & 224 & 95 & 567 & 3.44 & Baik \\
\hline & $\mathrm{X} 21$ & 0 & 22 & 177 & 276 & 130 & 605 & 3.67 & Baik \\
\hline & $\mathrm{X} 22$ & 1 & 14 & 180 & 276 & 140 & 611 & 3.70 & Baik \\
\hline & $\mathrm{X} 23$ & 1 & 48 & 168 & 268 & 85 & 570 & 3.45 & Baik \\
\hline Total & & & & & & & & 53.90 & \\
\hline Rata-Rata & & & & & & & & 3.59 & Baik \\
\hline
\end{tabular}

Berdasarkan Tabel 4 ditemukan bahwa persepsi pelanggan terhadap penerapan protokol kesehatan dalam upaya meningkatkan kualitas pelayanan selama era New Normal pada 15 Restoran di Kota Denpasar, dilihat dari dimensi pelayanan Makanan dan minuman mendapat nilai rata-rata 3.59 yang berarti baik. Ini menunjukkan bahwa penerapan protokol kesehatan pada 15 restoran di Kota Denpasar di dimensi pelayanan makanan dan minuman sudah diterapkan dengan baik, namun masih ada 4 variabel yang menunjukkan nilai cukup baik, yaitu variable pengaturan jarak duduk tamu dengan pemasangan partisi antar tamu di atas meja tidak ada yang memasang tapi ada yang memberi tanda silang sebagai petunjuk dilarang duduk dan itu menunjukkan sudah memberi jarak antar tamu atau antar meja tamu. Untuk menu yang digunakan masih banyak yang menggunakan menu offline dan berbahan dasar kerta sehingga kesempatan 
dekat dan tatap muka masih ada saat taking order dan menu susah untuk dibersihkan dengan cairan disinfektan.

Tapi ada beberapa restoran sudah merubah sistem pengambilan pesanannya dengan merekam barcode atau membuat menu yang berbahan dasar plastik sehingga mudah dan aman dibersihkan dengan bahan disinfektan. Berdasarkan pengamatan langsung terlihat bahwa semua restoran masih menyajikan makanan ke meja tamu tanpa menggunakan penutup makanan. Selain itu pada saat pembayaran staf restoran jarang menyarankan secara khusus kepada tamu untuk membayar dengan non tunai, tapi sudah menyediakan pembayaran secara non tunai. Penyajian makanan dengan penutup makanan sangat efektif untuk menghindari terkontaminasinya makanan dengan virus ataupun mikroorganisme yang berbahaya yang bertebaran di udara seperti virus corona. Untuk itu sangat penting menutup makanan saat akan menyajikan ke meja tamu apalagi jarak yang cukup jauh dari dapur ke restoran.

Sedangkan untuk dimensi pembayaran dan pintu keluar, persepsi pelanggan terhadap penerapan protokol kesehatan guna meningkatkan kualitas pelayanan pada 15 restoran di Kota Denpasar, sebanyak 165 orang dapat dilihat pada Tabel 5 Pada tabel tersebut akan ditunjukkan rangkuman nilai jawaban dari masing-masing variable yang meliputi 10 variabel.

Tabel 5: Distribusi Frekuensi Nilai Jawaban Responden dari Dimensi Pembayaran dan Pintu Keluar

$$
(\mathrm{N}=165)
$$

[Sumber : Data olahan]

\begin{tabular}{|c|c|c|c|c|c|c|c|c|c|}
\hline \multirow[b]{2}{*}{ Dimensi } & \multirow[b]{2}{*}{ Variabel } & \multicolumn{5}{|c|}{ Nilai Jawaban } & \multirow{2}{*}{$\begin{array}{l}\text { Total } \\
\text { Nilai }\end{array}$} & \multirow{2}{*}{$\begin{array}{c}\text { Rata } \\
- \\
\text { Rata }\end{array}$} & \multirow[t]{2}{*}{ Keterangan } \\
\hline & & $\begin{array}{c}\text { STB } \\
\text { (1) }\end{array}$ & $\begin{array}{l}\text { TB } \\
\text { (2) }\end{array}$ & $\begin{array}{l}\text { CB } \\
\text { (3) }\end{array}$ & $\begin{array}{c}\text { B } \\
\text { (4) }\end{array}$ & $\begin{array}{l}\text { SB } \\
\text { (5) }\end{array}$ & & & \\
\hline & $\mathrm{X} 24$ & 3 & 78 & 216 & 144 & 75 & 516 & 3.13 & Cukup Baik \\
\hline & $\mathrm{X} 25$ & 1 & 92 & 177 & 180 & 70 & 520 & 3.15 & Cukup Baik \\
\hline & $\mathrm{X} 26$ & 2 & 44 & 135 & 240 & 180 & 601 & 3.64 & Baik \\
\hline Pembayaran & $\mathrm{X} 27$ & 2 & 62 & 189 & 184 & 115 & 552 & 3.35 & Cukup Baik \\
\hline Dan & $\mathrm{X} 28$ & 2 & 82 & 162 & 164 & 135 & 545 & 3.30 & Cukup Baik \\
\hline \multirow[t]{5}{*}{ Pintu Keluar } & $\mathrm{X} 29$ & 1 & 48 & 78 & 228 & 285 & 640 & 3.88 & Baik \\
\hline & X30 & 2 & 18 & 123 & 244 & 260 & 647 & 3.92 & Baik \\
\hline & X31 & 4 & 78 & 165 & 196 & 90 & 533 & 3.23 & Cukup Baik \\
\hline & X32 & 14 & 134 & 144 & 128 & 20 & 440 & 2.67 & Cukup Baik \\
\hline & X33 & 15 & 146 & 114 & 140 & 20 & 435 & 2.64 & Cukup Baik \\
\hline Total & & & & & & & & 32.90 & \\
\hline Rata-Rata & & & & & & & & 3.29 & Cukup Baik \\
\hline
\end{tabular}

Berdasarkan Tabel 5 ditemukan bahwa persepsi pelanggan terhadap penerapan protokol kesehatan dari segi pembayar dan pintu keluar pada 15 restoran di Kota Denpasar, Ball secara keseluruhan adalah cukup baik dengan nilai rata-rata sebesar 3.29. Hal ini berdasarkan pada penilaian pelanggan yang menyatakan bahwa sebagian besar variable penerapan protokol kesehatan di saat pembayaran dan pintu keluar belum diterapkan secara optimal karena jarang restoran mengatur jalur keluar masuk tamu dengan memberi batasan atau partisi agar tidak berpapasan saat keluar masuk namun yang ada adalah memisahkan pintu masuk dan keluar bagi tamu. Kemudian di kasir ada beberapa yang menggunakan pembatas atau partisi tapi kebanyakan tidak menggunakan partisi hanya menyediakan hand sanitizer. Untuk tempat cuci tangan lebih banyak 
disediakan di dekat toilet, saat pintu masuk, tapi jarang didekat kasir. Selain untuk penghematan juga karena space yang tidak memungkinkan. Pengaturan antrean pembayaran tidak semua menerapkan dengan memberi tanda berdiri atau pembatas, kembali lagi dilihat dari space yang ada kurang memungkinkan untuk diberi pembatas karena sempit areanya atau di masa pandemic seperti ini sedikit pelanggan yang datang. Begitu juga dengan pemasangan peta lokasi titik kumpul jarang terpasang di restoranrestoran namun ada beberapa yang memasang seperti tempat bermain untuk anak-anak yang tersedian di restoran dan jalur evakuasi.

Tabel 6: Rekapitulasi Persepsi Pelanggan Secara Keseluruhan Terhadap Penerapan Protokol Kesehatan Pada 15 Restoran di Kota Denpasar, Bali.

\begin{tabular}{clcc}
\hline NO. & DIMENSI & RATA - RATA & KETERANGAN \\
\hline 1 & Penerimaan (Area Pintu Masuk) & 3.14 & Cukup Baik \\
2 & Pelayanan makanan dan Minuman & 3,59 & Baik \\
3 & Pembayaran dan Pintu keluar & 3.29 & Cukup Baik \\
\hline & Rata - rata & $\mathbf{3 . 3 4}$ & Cukup Baik \\
\hline
\end{tabular}

Berdasarkan tabel 6 diperoleh hasil bahwa penilaian pelanggan secara keseluruhan terhadap penerapan protokol kesehatan dalam upaya meningkatkan kualitas pelayanan selama era New Normal pada 15 restoran di Kota Denpasar, Bali, mendapat nilai rata-rata 3.34 yang dalam hal ini termasuk dalam katagori cukup baik.

\subsection{Pembahasan}

Berdasarkan ketiga tabel tersebut di atas maka dapat dirangkum dalam tabel berikut mengenai persepsi pelanggan terhadap penerapan protokol kesehatan dalam upaya meningkatkan kualitas pelayanan selama era New Normal pada 15 restoran di Kota Denpasar, Bali.

\section{KESIMPULAN}

Berdasarkan pembahasan pada bab sebelumnya didapatkan kesimpulan bahwa persepsi pelanggan secara keseluruhan terhadap penerapan protokol kesehatan dalam upaya meningkatkan kualitas pelayanan selama era New Normal pada 15 restoran di Kota Denpasar, Bali, mendapat nilai rata-rata 3.34 yang dalam hal ini termasuk dalam katagori cukup baik. Ini menunjukkan bahwa ke-15 restoran yang juga menjadi rekomendasi dari Tripadvisor belum menerapkan protokol kesehatan sesuai Panduan Pelaksanaan Cleanliness, Health, Safety and Environmental Sustainability (CHSE) atau yang selanjutnya disebut Panduan Pelaksanaan Kebersihan, Kesehatan, Keselamatan, dan Kelestarian Lingkungan di Restoran/Rumah Makan dengan optimal. Karena ada beberapa variable pada dimensi penerimaan tamu dan dimensi pembayaran tidak dilakukan dengan baik, padahal dimensi ini sangat riskan bagi penyebaran atau terpaparnya virus corona.

\section{DAFTAR PUSTAKA}

Erfiana, W.I. (2014). Service Quality Analysis for Customer Satisfaction in Japanese Saboten Shokudo Malang.

Hendriyani, I. G. A. D. (2018). The Importance of Physical Environment for Guest at Restaurants in Bali. Journal of Tourism and Hospitality Manangement.

Hendriyani, I. G. A. D., Magdalena, L. \& Ariesta, N. P. A (2019) Persepsi Pelanggan Terhadap Kualitas Pelayanan Dan Peranan Lingkungan Fisik Pada Restoran Di Kota 
Denpasar-Bali. Jurnal Kepariwisataan : Pusat penelitian dan Pengabdian Kepada Masyarakat STP Nusa Dua Bali

Kementerian Pariwisata dan Ekonomi Kreatif/ Badan Pariwisata dan Ekonomi Kreatif. (2020). Panduan Pelaksanaan Kebersihan, Kesehatan, Keselamatan, dan Kelestarian Lingkungan di Restoran/Rumah Makan. Jakarta. Edisi Juli

Kusmayadi \& Sugiarto, E. (2000). Metode Penelitian dalam Bidang Kepariwisataan. Jakarta: PT. Gramedia Pustaka Utama.

Mantra, I. B., \& Kasto. (1989). Penentuan Sampel dalam Metode Penelitian Survai, Editor Masri Singarimbun dan Sofian Effendi. Jakarta: LP3ES

Supranto, J. (2004). Pengukuran Tingkat Kepuasan Pelanggan Untuk Menaikkan Pangsa Pasar. Jakarta: Rineka Cipta.

Tusukan, et.al. (2016). The Important of Restaurant Physical Environment For Turkish Customers. J Tourism Res Hospitality. Journal of Tourism. Research and Hospitality. Turkey

Wall E.A. \& Berry L.L. (2007). The combined effects of the physical environment and employee behavior on customer perception of restaurant service quality. Cornell Hotel Restaurant Adm Q 48: 59-69. 